\title{
Different Gender, Different Arabic? The Case of Israel ${ }^{1}$
}

\author{
Torkel Lindquist \\ Uppsala University, Sweden
}

\begin{abstract}
The present article indicates that women and men write different Arabic in the Israeli press. These differences are observable in the frequency of main and secondary clauses (i.e. in sentence length and in variation), in word order, in the frequency of clauses containing adjectives, as well as those containing adverbs. We see these differences in the frequency of verbs without any visible noun, as well as in the choice of conjunction and the choice of particle of negating the past. These variations in Modern Standard Arabic (MSA) are due to the gender of the reader, as is the case with adjectives, where women writers use markedly fewer adjectives than men do, except when writing for men. But the variation is otherwise dependent on the gender of the writer. This alternation is not between grammatical or ungrammatical Arabic. Indeed, both genders write correct Arabic. Instead it is (mostly) a question of choice, of style.
\end{abstract}

1 With the generous support of the Swedish Research Council (Vetenskapsrådet) and due to the hospitality of the Moshe Dayan Center at Tel Aviv University I was able 2007-9 to conduct research on the thrilling subject of contact induced grammatical change. I would like to express my gratitude to several colleagues at Uppsala and Tel Aviv University, foremost to Prof. Eyal Zisser, Prof. Withold Witakowski, Dr. Tal Davidovich, Director Chaim Gal, Prof. Ilai Alon and doctoral student Michael Barak. 
Keywords: Arabic, Israel, Media, Gender, Linguistic, Modern Standard Arabic, Syntax, Men, Women, Differences

The focus of this article lies on differences in the written Arabic of men and women in the Israeli press. Emphasis is on linguistic features such as morphology and syntax ${ }^{2}$

A multitude of research has been made during the last century on the importance of gender in relation to language use. ${ }^{3}$ One of the pioneers was Otto Jespersen, who encountered a language among Indians in Bolivia that presented clear differences when men in relation to women used it. These differences appeared in the morphology, the syntax and the lexicon. As a universal rule, Jespersen suggested the following: that women, i.e. all over the world, are more conservative while men on the one hand use more archaic language forms and, at the same time, are more open to including new terminology. Men, further, have a more technical language and construct more complicated sentences with successive secondary clauses, and secondary clauses within secondary clauses. Women, on the other hand, according to him, rather use main clauses bound together by the conjunction 'and'. The reasons behind the differences are found, according to Jespersen, not so much in the gender as in differences in social rank. He referred to another language, as an historical comparison: In India women spoke the vulgar language 'Prakrit', while men spoke the colourful 'Sanskrit'.

Two decades later, Edward Sapir claimed to have found a language that expressed gender differences the most clearly: 'Jana' of eastern California, a language that lacked gender, but where men used other verbs than women in describing the same act, by adding special

2 Other studies emphasized aspects such as stereotypes, as does e.g. S. Mills, Language and Sexism (New York 2008), pp. 126 ff.

3 The term 'gender' refers to socially expected characteristics that are possibly different between men and women. The term 'sex' on the other hand is wrong in this connection as it indicates differences in a biological sense. See A. Goddard and L. M. Patterson, Language and Gender (London 2000), p. 1.

4 O. Jespersen, Language, Its Nature, Development and Origin (London 1922), 237-254. 
endings. Sapir considered whether social taboos could be behind these differences but found it most unlikely as women had been documented using male terminology when quoting men. Rather, he too was of the opinion that the determining factor lies in unequal social ranks of men and women. ${ }^{5}$

Mary R. Haas introduced the importance of the receiver for how the language is used. In contrast to the former studies, she found, in 'Koasati' of South East Louisiana that women were the ones with the most archaic lexica and, also, that the generational aspect was important. Older women used more archaic forms, while younger women spoke more like men. ${ }^{6}$

Japanese is one of the more famous languages with recorded differences between the genders. Thus Janet Shibamoto claimed that Japanese women not only have special terminology, just for women, but also special endings that are affixed to words. ${ }^{7}$ Women furthermore have a tendency to reduce syllables in nouns. In prose text in journals, she presented syntactical variation between the genders in that women's prose more frequently ended with a noun than did men's. In Japanese, men on the other hand seemed to use more adverbs. ${ }^{8}$ As above, it was also the opinion of Bernard Saint-Jacques that social dependency and social rank explain why gender influences the language, whether it is the gender of the speaker or the listener, and that this fact might be a universal phenomenon. ${ }^{9}$ In Japanese, in particular, there appears to be a historical prejudice going back to the formation of a national language, where women are noted to use

5 E. Sapir, Selected Writings in Language (Berkeley 1949), 206-212.

6 M. J. Haas, 'Men's and Women's Speech in Koasati', in D. Hymes (ed.), Language in Culture and Society (New York 1964), 228-233.

7 For example 'word' + MOZI, 'word' + MOMO, or before the word, as O + 'word'. J. S. Shibamoto, Japanese Women's Language (London 1985), 29-169.

8 They reduce syllables from nouns, for example MATU for MATUTAKE (mushroom). Ibid, 29-169. See also W. Grootaers, 'Quelques remarques concernant le langage des femmes', in Orbis 1 (1952), 82-85; R. A. Miller, The Japanese Language (Chicago 1967), 277, 283-290; M. Y. Lee, 'The Married Women's Status and Role as Reflected in Japanese: an Exploratory Sociolinguistic Study', in Signs 1 (1976), 991-999.

9 B. Saint-Jacques, 'Sex, Dependency and Language', in La Linguistique 9 (1973), pp. 89-96. 
official Japanese ungrammatically, or rather in Japanese, ‘impolitely', without formal grammatical forms of respect. ${ }^{10}$

Several leading researchers during the 1970s and 1980s were of the opinion that the main difference between the language of men and women was that women very reluctantly change the language they once learned, i.e. that they are more conservative in this sense. However, at the same time, it is women who use more new forms. ${ }^{11}$

In a study on power-relations between the genders, Noelle Moreau presented the opinion that differences in language use exist, and that these differences are due to unequal identities and powerrelations. ${ }^{12}$ Smith had a similar thinking some years earlier. He made the conclusion that as the internal relations between the genders (culturally, psychologically, in terms of power) vary from one society to another, it must be concluded that gender then also will influence language in varying degrees in different societies. ${ }^{13}$ Not to be forgotten in this context also is later research on 'Language and Power', where language is considered not in the first place a consequence of inequality in society, but rather quite the opposite, where focus lies on the function of language to reinforce these material and ideological patterns in society. ${ }^{14}$

Indeed, examples of previous research in the field give a rather fragmented picture. 'Gender and Language' includes fields as apart as

10 M. Inoue, 'Echoes of Modernity: Nationalism and the Enigma of "Women's Language” in Late Nineteenth Century Japan', in B. S. McElhinny, (ed.), Words, Worlds and Material Girls: Language, Gender, Globalization (New York 2007), 157-204.

11 W. Labov, Sociolinguistic Patterns (Philadelphia 1972), 243-244, 301-304; R. W. Fasold, Tense Marking in Black English: a Linguistic and Social Analysis (Arlington 1972), 215-217; M. R. Key, Male/Female Language (New York 1975); J. Silveira, 'Generic Masculine Words and Thinking', in C. Kramarae, The Voices and Words of Women and Men (Oxford 1980), 165-178; and M. Hellinger, 'Effecting Social Change through Group Action', in C. Kramarae, M. Schultz and W. O’Barr (eds.), Language and Power (Los Angeles 1984), pp. 136-153.

12 N. B. Moreau, 'Education, Ideology and Class/Sex Identity', in C. Kramarae, M. Schultz and W. O’Barr (eds.), Language and Power (Los Angeles 1984), 43-61.

13 P. M. Smith, 'Sex Markers in Speech', in I. K. Sherer and H. Giles, Social Markers in Speech (Cambridge 1979), 109-146.

14 N. Fairclough, Language and Power (London 2001). 
stereotypes, power-relations, social or practical purposes with the language ${ }^{15}$ the use of specific phrases by each gender, ${ }^{16}$ sentence length, ${ }^{17}$ or what gender utilizes which words. ${ }^{18}$ Some theorists even argue against the very existence of meaningful differences in the language of men and women. ${ }^{19}$

When it comes to research most related to this study, i.e. on grammar and sentence length, Malka Muchnik shows in her work on Hebrew press language in Israel that men and women as writers adapt their style stereotypically according to what the reader is expected to want according to the gender of the reader. Her conclusion is that what is most important is not the gender of the writer but rather of the receiver, something that is clearly expressed as both genders adapt their styles in the same way. Both men and women will in Hebrew e.g. use more adjectives in an article intended for women. On the whole, she finds only minor differences in men's and women's language. One of these, in Hebrew, is that women use vulgar language (slang) less than men. ${ }^{20}$

Muchnik uses the following method in order to reveal variation depending on the gender of the reader: she divides all articles she examined into three categories, one where the intended audience is female, one where it is male, and one where the material is supposedly interesting for both genders. ${ }^{21}$

15 A. Colley et al., 'Style and Content in Emails and Letters to Male and Female Friends', in Journal of Language and Social Psychology, 23 (2004), pp. 369378.

16 This subject was first introduced by R. Lakoff, Language and Women's Place (New York 1975).

17 A. Mulac and T. L. Lundell, 'Effects of Gender-Linked Language Differences in Adults' Written Discourse: Multivariate Tests of Language Effects', in Language and Communication 14 (1994), pp. 299-309. Women are found to use longer sentences, while men, overall, use more words.

18 A. Mulac et al., 'Empirical Support for the Gender-as-Culture Hypothesis: an Intercultural Analysis of Male/Female Language Differences', in Human Communication Research (2001), pp. 121-152. In this and other studies women are found using more intensive adverbs and more conjunctions.

19 A. Weatherall, Gender, Language and Discourse (London 2002).

20 M. Muchnik, 'Language Differences between Men and Women in Hebrew Journals' (Ramat-Gan 1992), 213-222, Ph.D. thesis in Hebrew.

21 Ibid. The presentation of a subject as 'interesting for men' or 'interesting for women' is based on stereotypes and as such controversial. Fields of interest 
In this study, too, half of the articles examined have been written by men and half by women. The articles are also divided into three groups or headings. When it comes to "topics of interest" for the one or the other gender, the articles will be examined to verify any tendency of variation in comparison to articles of common interest. But an average frequency of the gender will also be considered separately. No article without signature will be considered. Furthermore, while the articles vary in size, between some 1500 and 10.000 words, they all have in common that the chosen length is long enough to let the writer express his or her Arabic in such a way that makes variation possible.

The statistical frequency of the following grammatical features will be registered in each article:

1) Syntax:

a) Word Order in main clauses;

I) with order SV...;

II) with order VS...;

b) the frequency of equational sentences, here defined as nominal sentences without the presence of a verb. These therefore do not include sentences with kāna or any of her sisters, i.e. verbs denoting any aspect of 'to be';

c) the frequency of sentences consisting of verbs without any visible noun. That is, the noun is expressed in the verb itself, as 'aktobo (I + write). These are many times written in first person;

d) Verbs in passive voice;

e) Secondary clauses;

I) with SV... order following 'inna or any of her sisters;

only or mostly to men would be sports, automotive, business, etc., while those of interest mostly or solely to women would be articles on the home, family and beauty. This is according to "topics of male" and "topics of female" interest according to Haas and Weil respectively. A. Haas, 'Male and Female Spoken Language Differences', in Psychological Bulletin 86 (1979), 616-626; Sh. Weil, 'Women and Language in Israel', in International Journal of the Sociology of Language 41 (1983), 77-91. 
II) with SV... order where the subject is a relative pronoun, i.e. referring to a definite noun;

III) With SV... order where the subject is not visible but refers to an indefinite noun;

f) Secondary clauses;

I) with VS... order where the relative pronoun is not the subject of the verb beginning the clause;

g) Verbs in the subjunctive;

2) Further, the frequency of

a) Adjectives, either as predicates or describing a noun as subject of the clause or as object or as adverb. Only one occurrence of adjectives in each clause will be counted;

b) Adverbs indicating the reason for an act, circumstantial, or indicating time or space;

c) Particles of negation I) lam; II) $m \bar{a}$;

d) Conjunctions, disregarding the many different grammatical functions of I) $w a-$; and II) $f a-$;

There are of course other grammatical features that possibly would expose variations both in grammar and in style. ${ }^{22}$ Sequences of verbs connected with a conjunction and thus referring to the same subject will be counted separately, that is each as a separate clause.

The results of the above are presented in tables. Also, noted ungrammaticalities, such as errors in Agreement, inappropriate case, lacking particles, lacking verbs, etc. will also be registered in the tables. ${ }^{23}$

22 Examples of other such features are the frequency of the Imperative, or the Jussive (apart from the one case above), preference for using $s a$ - or sawfa as a particle expressing future, or the use of ' $a$ - or $h a l$ as interrogative marker. After reading through a larger amount of material from which the articles were chosen, the frequency of these seemed to be rather insignificant. Therefore they will not be considered.

23 This is due to the possibility of a correlation between certain grammatical features and increased grammatical errors, and that this would be different for men and women. 
In order to select the research material, all the articles, according to the methodological considerations above, have been examined in the following examples of Israeli press written in Arabic. All are published once a week. The editions are furthermore not from the same day. ${ }^{24}$

24 1. al-Salām is a Christian weekly distributed for free. The edition of 2nd Jan. 2009 has only unsigned articles, with two exceptions, both written by men. $\mathbf{2}$. Hadīt al-nās is a weekly with no defined political or religious affiliation. It is sold. The edition of 5th Dec. 2008 has ten signed articles of an appropriate size, two of which are written by women. 3. Kull al-'arab is a weekly with no defined political or religious affiliation. It is sold. The edition of 5th Dec. 2008 has a total of 19 articles with signatures. Of these, three are written by women. 4. al-Ittih $\bar{a} d$ is the Arabic version published by the Israeli Communist Party. It is a weekly. The edition of 19-20th Dec. 2008 has 13 articles with signatures. One of the signatures belongs to a woman. 5. Bānōrāma is a weekly that is sold. It has no particular affiliation in terms of politics or religion. The edition of 5th Dec. 2008 has 20 signed articles, of which three are written by women. 6. al$A k h b \bar{a} r$ is a weekly distributed for free. Its political or religious leanings are not defined. The edition of 2nd Jan. 2009 has seven signed articles. The writers are all men. 7. al- 'Onwān al-ra'īsì is a weekly distributed for free. Its religious and political direction is undefined. The edition of 2nd Jan. 2009 has 13 articles with signatures. Three are written by women. 8. al-Sinārah is a weekly that is sold. Its politics and religious affiliation are undefined. The edition of 2nd Jan. 2009 has 28 articles with signatures. Two of these are written by women. 9. Sawt alJalīl is a free weekly. Its political or religious affiliations are undefined. The edition of 2nd Jan. 2009 has three signed articles, of which one is written by a woman. 10. Sawt al-'arabī is a weekly distributed free of charge, with no defined political or religious affiliation. The edition of 2nd Jan. 2009 has seven articles. One of these is written by a woman. 11. al-Markaz is a free weekly. Its political as well as religious affiliation is undefined. The edition of 2nd Jan. 2009 has twelve signed articles. Two are written by women. 12. 'Arab al-Dākhil is a weekly distributed free of charge. No political or religious affiliation is defined. The edition of 2nd Jan. 2009 has nine signed articles. Two are written by women. 13. al-Fajr al-jadìd is a weekly that is sold. No political or religious affiliation is defined. The edition of 2nd Jan. 2009 has no signed articles. 14. Laylek of June 2009 is a weekly magazine that is sold. It has no religious or political affiliation, and its intended audience is women.

It is my opinion that the variation in time will have no relevant effect on the results. When, however, it comes to the content, a rather large number of articles deal with the then ongoing intensified conflict between Israel and Hamas/the Gaza strip. This is naturally reflected in an unusually large number of articles about Gaza. 
There are also other publications in Arabic in Israel. These above are, however, the most circulated. From all of the articles above, the following equal number of articles by both genders will be chosen. ${ }^{25}$ In connection to the gender of the writer, a brief presentation of the content is presented.

Group one includes articles of interest mostly for women. I have chosen from Bānōrāma p. 40 an article written by a woman $(\mathbf{W})^{26}$ about a woman marrying against her will: working name (B1). Henceforth only the abbreviation is written in parentheses without explanation. The second article is from Laylek p. 70. (W) on the subject of love and fear, (L1). The third article comes from the same magazine, pp. 64-5. (W), a specialist giving advice on the subject of very sensitive children, (L1b). The fourth article is from Laylek, p. 70. (M), and the subject deals with primitive Islamic practices in Saudi Arabia, (L2). The last article in this group also comes from the same magazine, (M) writing on the duties of men and women in life and marriage, (L2b).

Group 2 includes articles of interest mostly for men. The chosen articles here are from the sports section. In al-Sinārah p. 7 reports (W) on kick-boxing in Israel, (S1). (M) in the same newspaper, p. 6, writes on the miserable results for Kfar Kana in the football competition, (S2). (W) from Kull al- 'arab, p. 33, writes on the first Arab woman judge in basketball in Israel, (K1b). ${ }^{27}$ Also the last article in this group is from the same paper, p. 30. (M) writes on negotiations in Jerusalem concerning unacceptable behaviour on the part of the Jewish audience toward a visiting Arab football team, (K2b). ${ }^{28}$

Group 3 includes articles of assumed interest for both genders. The first article is (M) in Bānōrāma p. 18. The subject is the social value of sending SMS, (B2). (W) writes in Kull al- 'arab p. 29 on a

25 The unequal number in the groups reflects a lesser frequency of articles intended mostly for men or women respectively.

26 In order to simplify for the reader, a female writer is marked as (W) and a male writer as (M).

27 Even the name of the section indicates the intended audience: riyā (Sports and young men).

28 That the articles are taken from the same newspaper is due to the comparability in size between articles written by men and women. Rather few articles are on the whole signed by women. This is particularly so in the sports section. 
letter from a child in Gaza, (K1). On the same page in the same paper (M) writes on the Arab propaganda effort to declare Jerusalem 'Arab capital of culture', (K2). The next article is written by (W) from 'Arab al-Dākhil p. 13 on the subject of children's reactions when watching TV reports from Gaza, (AD1). Also the following writer, (M), writes in the same paper, p. 8, and writes, or rather rewrites, the history of the city of Gaza, (AD2). (W) writing for Șawt al- 'arabī p. 9 has the next article on the subject of encouraging Gaza, (SalA1). (M) in the same paper, p. 7, writes on the subject of demonstrations for Gaza in the world, (SalA2). Finally, there are two articles chosen from al'Onwān al-ra' 'isī. (W) writes on p. 26 on the memory that comes after the ongoing conflict, (UR1), and (M) writes on the same page on Palestinian culture in the year that passed, (UR2).

\section{The results}

The following three tables give the frequency in each group for each individual publication. The last column gives the average frequency in the group.

Table of frequency no 1: articles of interest mostly to women (in percent of total)

\begin{tabular}{|l|l|l|l|l|l|l|}
\hline Category: syntax & B1 & L1 & L1b & L2 & L2b & Av. \\
\hline Main clause; SV... & 18.4 & 13.2 & 31 & 20.6 & 13.2 & 19.28 \\
\hline Main clause; VS... & 9.2 & 5.3 & 4.4 & 26.5 & 42.8 & 17.64 \\
\hline $\begin{array}{l}\text { Main clause; without } \\
\text { verb }\end{array}$ & 8.2 & - & 12.4 & 8.8 & 7.9 & 7.46 \\
\hline $\begin{array}{l}\text { Main clause; without } \\
\text { noun }\end{array}$ & 39.8 & 52.6 & 16.8 & 11.8 & 11.8 & 26.56 \\
\hline $\begin{array}{l}\text { Main clause; passive } \\
\text { voice }\end{array}$ & 1 & - & - & - & 1.3 & 0.46 \\
\hline
\end{tabular}




\begin{tabular}{|c|c|c|c|c|c|c|}
\hline $\begin{array}{l}\text { Total main } \\
\text { clauses }\end{array}$ & 76.6 & 71.1 & 64.6 & 67.7 & 78 & 71.6 \\
\hline $\begin{array}{l}\text { Secondary clause ; } \\
\text { SV after 'inna or her } \\
\text { sisters }\end{array}$ & 7.1 & - & 10.6 & 8.8 & 1.3 & 5.56 \\
\hline $\begin{array}{l}\text { Secondary clause; } \\
\text { SV after relative } \\
\text { pronoun }\end{array}$ & 6.1 & - & 2.7 & 8.8 & 3.9 & 4.3 \\
\hline $\begin{array}{l}\text { Secondary clause; } \\
\text { SV with hidden } \\
\text { relative pronoun } \\
\text { referring to } \\
\text { indefinite noun }\end{array}$ & 1 & 5.3 & 5.3 & 5.9 & 2 & 3.9 \\
\hline $\begin{array}{l}\text { Secondary clause; } \\
\text { VS where noun is } \\
\text { other than relative } \\
\text { pronoun }\end{array}$ & - & - & 1.8 & 5.9 & 1.3 & 1.8 \\
\hline $\begin{array}{l}\text { Secondary clause; in } \\
\text { the subjunctive }\end{array}$ & 5.1 & 23.7 & 15 & 2.9 & 14.5 & 12.24 \\
\hline $\begin{array}{l}\text { Total secondary } \\
\text { clauses }\end{array}$ & 19.3 & 29 & 35.4 & 32.6 & 23 & 27.86 \\
\hline Total clauses & 100 & 100 & 100 & 100 & 100 & 100 \\
\hline \multicolumn{7}{|l|}{$\begin{array}{l}\text { Category: } \\
\text { morphology and } \\
\text { word classes }\end{array}$} \\
\hline $\begin{array}{l}\text { Clauses with } \\
\text { adjectives }\end{array}$ & 20.4 & 21.1 & 38.1 & 67.6 & 23.7 & 34.18 \\
\hline $\begin{array}{l}\text { Clauses with adverbs } \\
\text { in the accusative or } \\
\text { written with } \\
\text { preposition }\end{array}$ & 9.1 & 2.6 & 24.7 & 17.7 & 4.6 & 11.74 \\
\hline
\end{tabular}




\begin{tabular}{|l|l|l|l|l|l|l|}
\hline $\begin{array}{l}\text { Frequency of } w a \text { in } \\
\text { relation to } f a-\end{array}$ & $88.9 / 11.1$ & $100 /-$ & $\begin{array}{l}86.5 / \\
13.5\end{array}$ & $\begin{array}{l}87.5 / \\
12.5\end{array}$ & $81.1 / 18.9$ & $\begin{array}{l}88.8 / \\
11.2\end{array}$ \\
\hline $\begin{array}{l}\text { Frequency of } \\
\text { negation } l a m \text { in } \\
\text { relation to } m \bar{a}\end{array}$ & $100 /-$ & $-/$ & $100 /-$ & $100 /-$ & - & $\begin{array}{l}75 / \\
25\end{array}$ \\
\hline $\begin{array}{l}\text { Number of } \\
\text { ungrammaticalities: } \\
\text { errors in agreement; } \\
\text { missing relative } \\
\text { pronouns... }\end{array}$ & 1 & 1 & 3 & - & 3 & 1.6 \\
\hline
\end{tabular}

Table of frequency no 2: articles of interest mostly to men (in percent of total)

\begin{tabular}{|l|l|l|l|l|l|}
\hline Category: syntax & S1 & S2 & K1b & K2b & Av. \\
\hline Main clause; SV... & 23.5 & 38.5 & 17.5 & 7.5 & 21.75 \\
\hline Main clause; VS... & 47.1 & 30.8 & 10.5 & 30.2 & 29.65 \\
\hline Main clause; without verb & - & - & 14 & 1.9 & 3.975 \\
\hline Main clause; without noun & 5.9 & - & 29.8 & 34 & 17.425 \\
\hline Main clause; passive voice & 17.6 & 3.8 & - & - & 5.35 \\
\hline Total main clauses & $\mathbf{9 4 . 1}$ & $\mathbf{7 3 . 1}$ & $\mathbf{7 1 . 8}$ & $\mathbf{7 3 . 6}$ & $\mathbf{7 8 . 1 5}$ \\
\hline $\begin{array}{l}\text { Secondary clause; SV after 'inna } \\
\text { or her sisters }\end{array}$ & 5.9 & - & 15.8 & 3.8 & 6.375 \\
\hline $\begin{array}{l}\text { Secondary clause; SV after relative } \\
\text { pronoun }\end{array}$ & - & 7.7 & 7 & 7.5 & 5.55 \\
\hline $\begin{array}{l}\text { Secondary clause; SV with hidden } \\
\text { relative pronoun referring to } \\
\text { indefinite noun }\end{array}$ & - & 3.8 & 1.8 & - & 1.4 \\
\hline
\end{tabular}




\begin{tabular}{|l|l|l|l|l|l|}
\hline $\begin{array}{l}\text { Secondary clause; VS where noun } \\
\text { is other than relative pronoun }\end{array}$ & - & 3.8 & 1.8 & 1.9 & 1.875 \\
\hline $\begin{array}{l}\text { Secondary clause; in the } \\
\text { subjunctive }\end{array}$ & - & 11.5 & 3.5 & 13.2 & 7.05 \\
\hline Total secondary clauses & $\mathbf{5 . 9}$ & $\mathbf{2 6 . 8}$ & $\mathbf{2 9 . 2}$ & $\mathbf{2 6 . 4}$ & $\mathbf{2 2 . 0 7 5}$ \\
\hline $\begin{array}{l}\text { Clauses with adjectives } \\
\text { Clauses with adverbs in the } \\
\text { accusative or with preposition }\end{array}$ & 29.4 & 11.5 & 10.5 & 17 & 17.1 \\
\hline $\begin{array}{l}\text { Total clauses } \\
\text { Frequency of } w a \text { in relation to } f a-\end{array}$ & $100 /-$ & $100 /-$ & $34.5 /$ & $7.1 /$ & $89.425 /$ \\
\hline $\begin{array}{l}\text { Frequency of negation lam in } \\
\text { relation to } m \bar{a}\end{array}$ & - & $100 /-$ & $100 /-$ & $100 /-$ & $100 /-$ \\
\hline $\begin{array}{l}\text { Number of ungrammaticalities: } \\
\text { relative pronouns, etc. }\end{array}$ & 2 & 2 & 1 & 1 & 1.25 \\
\hline
\end{tabular}


Table of frequency no 3; articles of interest to both genders (in percent of total)

\begin{tabular}{|l|l|l|l|l|l|l|l|l|l|l|}
\hline $\begin{array}{l}\text { Category: } \\
\text { syntax }\end{array}$ & B2 & K1 & K2 & AD1 & AD2 & SalA1 & SalA2 & UR1 & UR2 & Av. \\
\hline $\begin{array}{l}\text { Main clause; } \\
\text { SV... }\end{array}$ & 30.6 & 3.1 & 8.4 & 13.7 & 11 & 8.6 & 10.7 & 20 & 15.1 & 13.47 \\
\hline $\begin{array}{l}\text { Main clause; } \\
\text { VS... }\end{array}$ & 17.6 & 4.1 & 13.3 & 11.4 & 30.1 & 27.6 & 12.5 & 15.7 & 13.7 & 16.22 \\
\hline $\begin{array}{l}\text { Main clause; } \\
\text { without verb }\end{array}$ & 7.6 & 32 & 25.3 & 9.1 & 16.2 & 13.8 & 8.9 & 15.7 & 12.3 & 15.66 \\
\hline $\begin{array}{l}\text { Main clause; } \\
\text { without noun }\end{array}$ & 5.9 & 7.2 & 8.4 & 15.4 & 2.6 & 27.6 & 7.1 & 12.9 & 5.5 & 10.29 \\
\hline $\begin{array}{l}\text { Main clause; } \\
\text { passive voice }\end{array}$ & 1.8 & 2.1 & - & 4.6 & 10.3 & 3.4 & - & 1.4 & 8.2 & 3.53 \\
\hline
\end{tabular}




\begin{tabular}{|l|l|l|l|l|l|l|l|l|l|l|}
\hline $\begin{array}{l}\text { Total main } \\
\text { clauses }\end{array}$ & $\mathbf{6 4 . 5}$ & $\mathbf{4 8 . 5}$ & $\mathbf{5 5 . 4}$ & $\mathbf{5 4 . 2}$ & $\mathbf{7 0 . 2}$ & $\mathbf{8 1}$ & $\mathbf{3 9 . 2}$ & $\mathbf{6 6 . 2}$ & $\mathbf{5 4 . 8}$ & $\mathbf{5 9 . 3 3}$ \\
\hline $\begin{array}{l}\text { Secondary } \\
\text { clause; SV after } \\
\text { 'inna or her } \\
\text { sisters }\end{array}$ & 18.8 & 13.4 & 7.2 & 5.1 & 8.1 & 3.4 & 19.6 & 1.4 & 8.2 & 9.47 \\
\hline $\begin{array}{l}\text { Secondary } \\
\text { clause; SV after } \\
\text { relative pronoun }\end{array}$ & 5.3 & 6.2 & 9.6 & 13.1 & 16.9 & - & 28.6 & 5.7 & 16.4 & 11.31 \\
\hline $\begin{array}{l}\text { Secondary } \\
\text { clause; SV with } \\
\text { hidden relative } \\
\text { pronoun referring } \\
\text { to indefinite noun }\end{array}$ & 2.4 & 24.7 & 9.6 & 3.4 & 3.3 & 1.7 & 7.1 & 11.4 & 12.3 & 8.43 \\
\hline $\begin{array}{l}\text { Secondary } \\
\text { clause; VS where } \\
\text { noun is other } \\
\text { than relative } \\
\text { pronoun }\end{array}$ & 2.4 & 2.1 & 2.4 & 0.6 & 4.8 & - & 1.8 & - & - & 1.57 \\
\hline
\end{tabular}


TORKEL LINDQUIST

\begin{tabular}{|c|c|c|c|c|c|c|c|c|c|c|}
\hline $\begin{array}{l}\text { Secondary } \\
\text { clause; in the } \\
\text { subjunctive }\end{array}$ & 7.1 & 5.2 & 14.4 & 21.7 & 7.7 & 13.8 & 3.6 & 14.7 & 8.2 & 10.71 \\
\hline $\begin{array}{l}\text { Total secondary } \\
\text { clauses }\end{array}$ & 36 & 51.6 & 43.2 & 43.9 & 40.8 & 18.9 & 60.6 & 29.9 & 45.1 & 41.11 \\
\hline $\begin{array}{l}\text { Clauses with } \\
\text { adjectives }\end{array}$ & 46.5 & 17.5 & 38.6 & 20 & 33.1 & 15.5 & 73.2 & 61.4 & 57.5 & 40.36 \\
\hline $\begin{array}{l}\text { Clauses with } \\
\text { adverbs in the } \\
\text { accusative or } \\
\text { written with } \\
\text { preposition }\end{array}$ & 22.4 & 7.2 & 2.4 & 8 & 15 & 1.7 & 16.1 & 14.3 & 12.3 & 11.044 \\
\hline Total clauses & 100 & 100 & 100 & 100 & 100 & 100 & 100 & 100 & 100 & 100 \\
\hline $\begin{array}{l}\text { Frequency of } w a \\
\text { in relation to } f a-\end{array}$ & $\begin{array}{l}88.9 / \\
11.1\end{array}$ & $\begin{array}{l}94.4 / \\
5.6\end{array}$ & $\begin{array}{l}84.1 / \\
15.9\end{array}$ & $\begin{array}{l}78.4 / \\
21.6\end{array}$ & $\begin{array}{l}85.8 / \\
14.2\end{array}$ & $\begin{array}{l}76.5 / \\
23.5\end{array}$ & $\begin{array}{l}89.3 / \\
10.7\end{array}$ & $\begin{array}{l}79.2 / \\
20.8\end{array}$ & $\begin{array}{l}100 / \\
-\end{array}$ & $\begin{array}{l}86.29 / \\
13.71\end{array}$ \\
\hline
\end{tabular}




\begin{tabular}{|l|l|l|l|l|l|l|l|l|l|l|}
\hline $\begin{array}{l}\text { Frequency of } \\
\text { negation } l a m \text { in } \\
\text { relation to } m \bar{a}\end{array}$ & $100 /$ & $100 /$ & - & $100 /$ & $66.7 /$ & $100 /$ & 85.7 & $100 /$ & $100 /$ & $93.7 /$ \\
\hline $\begin{array}{l}\text { Number of } \\
\text { ungrammaticali- } \\
\text { ties: errors in } \\
\text { agreement; } \\
\text { missing relative } \\
\text { pronouns }\end{array}$ & $\mathbf{5}$ & - & - & $\mathbf{9}$ & $\mathbf{6}$ & $\mathbf{1}$ & $\mathbf{2}$ & $\mathbf{6}$ & $\mathbf{2}$ & $\mathbf{3 . 4 4 4}$ \\
\hline
\end{tabular}


In order to make the results more comparable, the following table includes the average frequency in all three groups.

Table of frequency no 4: comparison of average results of every group (in percent of total)

\begin{tabular}{|l|l|l|l|}
\hline Category: syntax & $\begin{array}{l}\text { For } \\
\text { women }\end{array}$ & $\begin{array}{l}\text { For } \\
\text { men }\end{array}$ & $\begin{array}{l}\text { For both } \\
\text { genders }\end{array}$ \\
\hline Main clause; SV... & 19.28 & 21.75 & 13.47 \\
\hline Main clause; VS... & 17.64 & 29.65 & 16.22 \\
\hline Main clause; without verb & 7.46 & 3.975 & 15.66 \\
\hline Main clause; without noun & 26.56 & 17.425 & 10.29 \\
\hline $\begin{array}{l}\text { Main clause; passive voice } \\
\text { Total main clauses }\end{array}$ & 0.46 & 5.35 & 3.53 \\
\hline $\begin{array}{l}\text { Secondary clause ; SV after 'inna or } \\
\text { her sisters }\end{array}$ & 5.56 & 6.375 & 9.47 \\
\hline $\begin{array}{l}\text { Secondary clause; SV after relative } \\
\text { pronoun }\end{array}$ & 4.3 & 5.55 & 11.31 \\
\hline $\begin{array}{l}\text { Secondary clause; SV with hidden } \\
\text { relative pronoun referring to indefinite } \\
\text { noun }\end{array}$ & 3.9 & 1.4 & 8.43 \\
\hline $\begin{array}{l}\text { Secondary clause; VS where noun is } \\
\text { other than relative pronoun }\end{array}$ & 1.8 & 1.875 & 1.57 \\
\hline $\begin{array}{l}\text { Secondary clause; in the subjunctive } \\
\text { Total secondary clauses }\end{array}$ & 12.24 & 7.05 & 10.71 \\
\hline $\begin{array}{l}\text { Clauses with adjectives } \\
\text { or with preposition }\end{array}$ & $\mathbf{2 7 . 8 6}$ & $\mathbf{2 2 , 0 7 5}$ & $\mathbf{4 1 . 1 1}$ \\
\hline
\end{tabular}




\begin{tabular}{|l|l|l|l|}
\hline Total clauses & $\mathbf{1 0 0}$ & $\mathbf{1 0 0}$ & $\mathbf{1 0 0}$ \\
\hline Frequency of $w a$ in relation to $f a-$ & $88,8 /$ & $\begin{array}{l}89.425 / \\
10.4\end{array}$ & $\begin{array}{l}86.29 / \\
13.71\end{array}$ \\
\hline $\begin{array}{l}\text { Frequency of negation lam in relation } \\
\text { to } m \bar{a}\end{array}$ & $\begin{array}{l}75 / 2 \\
25\end{array}$ & $100 /-$ & $\begin{array}{l}93.7 / \\
6.3\end{array}$ \\
\hline $\begin{array}{l}\text { Number of ungrammaticalities: } \\
\text { errors in agreement; .missing relative } \\
\text { pronouns.etc. }\end{array}$ & 1.6 & 1.25 & 3.444 \\
\hline
\end{tabular}

If we then compare the average result between the genders in the different groups, the following is found, where ' $W$ ' indicates women and ' $M$ ' men (numbers indicate percentage, except last row):

Table of frequency no 5: comparison of average results within each gender

\begin{tabular}{|l|l|l|l|l|l|l|}
\hline Category: syntax & Wgr1 & Wgr2 & Wgr3 & Mgr1 & Mgr2 & Mgr3 \\
\hline Main clause; SV... & 20.87 & 20.5 & 11.35 & 16.9 & 23 & 15.6 \\
\hline Main clause; VS... & 6.3 & 28.8 & 14.7 & 34.65 & 30.5 & 17.44 \\
\hline $\begin{array}{l}\text { Main clause; without } \\
\text { verb }\end{array}$ & 6.87 & 7 & 17.65 & 8.35 & 0.95 & 14.6 \\
\hline $\begin{array}{l}\text { Main clause; without } \\
\text { noun }\end{array}$ & 36.6 & 17.85 & 15.76 & 11.8 & 22 & 5.9 \\
\hline $\begin{array}{l}\text { Main clause; passive } \\
\text { voice }\end{array}$ & 0.3 & 8.8 & 2.88 & 0.88 & 1.9 & 4.06 \\
\hline $\begin{array}{l}\text { Total main clauses } \\
\text { Secondary clause; SV } \\
\text { after 'inna or her sisters }\end{array}$ & $\mathbf{7 0 . 7 7}$ & $\mathbf{8 2 . 9 5}$ & $\mathbf{6 2 . 4 8}$ & $\mathbf{7 2 . 8 5}$ & $\mathbf{7 3 . 3 5}$ & $\mathbf{5 6 . 8 2}$ \\
\hline $\begin{array}{l}\text { Secondary clause; SV } \\
\text { after relative pronoun }\end{array}$ & 2.93 & 3.5 & 6.83 & 5.5 & 1.9 & 12.34 \\
\hline $\begin{array}{l}\text { Secondary clause; SV } \\
\text { with hidden relative } \\
\text { pronoun referring to } \\
\text { indefinite noun }\end{array}$ & 3.87 & 0.9 & 10.3 & 3.95 & 1.9 & 6.94 \\
\hline
\end{tabular}




\begin{tabular}{|c|c|c|c|c|c|c|}
\hline $\begin{array}{l}\text { Secondary clause; VS } \\
\text { where noun is other } \\
\text { than relative pronoun }\end{array}$ & 0.6 & 0.9 & 0.68 & 3.6 & 2.85 & 2.28 \\
\hline $\begin{array}{l}\text { Secondary clause; in the } \\
\text { subjunctive }\end{array}$ & 14.6 & 1.75 & 13.85 & 8.7 & 12,35 & 8.2 \\
\hline $\begin{array}{l}\text { Total secondary } \\
\text { clauses }\end{array}$ & 27.9 & 17.55 & 36.08 & 27.8 & 26.6 & 45.14 \\
\hline Clauses with adjectives & 26.53 & 45.75 & 24.1 & 45.65 & 52.6 & 43.78 \\
\hline $\begin{array}{l}\text { Clauses with adverbs in } \\
\text { the accusative or with } \\
\text { preposition }\end{array}$ & 12.13 & 19.95 & 7.8 & 11.15 & 14.25 & 13.64 \\
\hline Total clauses & 100 & 100 & 100 & 100 & 100 & 100 \\
\hline $\begin{array}{l}\text { Frequency of } w a \text { in } \\
\text { relation to } f a \text { - }\end{array}$ & $\begin{array}{l}91.8 / \\
8.2\end{array}$ & $\begin{array}{l}82.75 / \\
17.25\end{array}$ & $\begin{array}{l}82.13 / \\
17.87\end{array}$ & $\begin{array}{l}84.3 / \\
15.7\end{array}$ & $\begin{array}{l}96.1 / \\
3.9\end{array}$ & $\begin{array}{l}89.62 / \\
10.38\end{array}$ \\
\hline $\begin{array}{l}\text { Frequency of negation } \\
\text { lam in relation to } m \bar{a}\end{array}$ & $\begin{array}{l}66.67 / \\
33.33\end{array}$ & $\begin{array}{l}100 / \\
-\end{array}$ & $\begin{array}{l}100 / \\
-\end{array}$ & $\begin{array}{l}100 / \\
-\end{array}$ & $\begin{array}{l}100 / \\
-\end{array}$ & $\begin{array}{l}89.5 / \\
10.5\end{array}$ \\
\hline $\begin{array}{l}\text { Number of } \\
\text { ungrammaticalities: } \\
\text { errors in agreement, } \\
\text { missing relative } \\
\text { pronouns, etc. }\end{array}$ & 1.3 & 1.5 & 4 & 2.3 & 1.5 & 3 \\
\hline
\end{tabular}

\section{Analysis}

The frequencies above reveal some variation among the groups as well as within one gender. It is probable that this kind of individuality is to be expected, as people are not robots, each having their individual style and preference in writing. Also, in all likelihood, this differentiation on an individual level would become less significant on a group level with a larger amount of articles. The average frequency takes out the extremes and in material ten times as voluminous, 
internal variation would be less significant. Smaller frequencies might also render differences in a larger amount of material. Here only differences of about 5 and more are considered.

There indeed seems to be some variation between how women and men write Arabic as well as variation depending on the gender of the supposedly intended reader.

a) Sentence length/relation main and secondary clauses: Starting with sentence length, based in this investigation on the number of clauses and the preference to use main clauses in relation to secondary clauses, a very interesting piece of information is revealed in table 4. In clauses intended mainly for men and mainly for women, respectively, the total of main clauses is over $70 \%$ ( 71.1 for women, 78.15 for men). This amounts to a difference of no less than 7 higher frequency of main clauses in articles written for men. However, in articles where the intended readers are both genders, less than $60 \%$ (59.33) of clauses are main clauses. Thus, the frequency of main clauses is about 18 less in articles addressing both genders than in articles addressed to men, and 11 less than in those addressed to women. It is to be noted that this relation is broken several times depending on the different kinds of main clauses that are registered in the table. Main clauses without a verb seem to be a much higher frequency in articles addressed to both genders (15.66), while the frequency is considerably weaker, approximately half, in articles addressed to women (7.46) and even more so in articles written for men (3.975).

While table 4 deals with the syntax, sentence length, word class and particles from the angle of the gender of the reader, table 5 gives us a more precise picture, taking up both the gender of the writers of the articles as well as the gender of the intended reader. Therefore table 5 has six columns, of which the first three are female writers in each of the three groups and the following three are male writers in the three groups. Again, the first group includes articles intended for women, the second articles for men, and the third articles written for both genders. The items under investigation are parallel to those in tables 1-3 and 4; and they are in the same order.

When looking at the total of main clauses, in table 5, the highest frequency in the use of these is when women write for men (as much 
as 83). This is about 26 more than the lowest frequency that can be found, namely in sentences written by men for both genders (only about 57). Three of the groups have frequencies of between 71 and 73.4. Further, sentences written by women for both genders have a main clause frequency of 62.5

Both genders (in tables 4 and 5) use passive voice with very low frequency in all groups. Replicating the findings of previous studies in other languages (from table 5), women in groups 1 and 3 tend to refrain from writing out any visible subject of the verb. Most of these verbs are written in the first person in the examined articles. ${ }^{29}$ Thus, a tendency in previous findings that women use the first person more often than men is reconfirmed also in Arabic. ${ }^{30}$

Main clauses without any verb, on the other hand could possibly indicate a difference only in group 2 (table 5), where women use more than men do.

The situation is then reversed when it comes to secondary clauses. There, in table 4, one finds no less than 40 in articles addressing both genders, while those intended for men include only 22 and those written for women, a somewhat higher 28. In the subcategories this tendency seems to be confirmed. In table 5 both genders have many more secondary clauses in articles intended for both genders, while men writing for men and women, respectively, use less than a third secondary clauses; less than a third of the clauses women use in articles addressing men are secondary clauses, and, slightly less than 20 in articles addressing women are secondary clauses.

Summary: In articles intended for both genders, where the writers are both men and women, the frequency of main clauses is considerably lower than in the articles for women. The highest frequency of main clauses is found in articles intended for men, clearly so when men write (82.95) and only slightly when women write. Secondary clauses in the tables.

30 Mehl and Pennebaker have found that women are more likely to use the first person singular. M.R. Mehl and J. W. Pennebaker, 'The Sounds of Social Life: a Psychometric Analysis of Students' Daily Social Environments and Natural Conversations', in Journal of Personality \& Social Psychology 84 (2003), pp. 857-870. 
are considerably more numerous in articles intended for both genders (while women use ten percent fewer than men do) as well as more in articles intended for women. Secondary clauses are an indication both of larger variation in the language as well as of sentence length. The frequency of secondary clauses is of exact parallel opposition to what is found in the main clauses. In contrast to the above main clauses, while the highest frequency of secondary clauses is to be found in sentences written by men in articles addressing both genders (45), the lowest is in sentences written by women for men (17.55). In three other groups the frequency varies between 26.5 and 28, and in the group of articles written by women addressing both genders it stands at 36. What these figures tell us is that women use fewer secondary clauses than men do both when writing for men (17.55 of all the clauses to 26.6) and when writing for both genders (36.8 in relation to 45.14). Only when writing for women, do women use about the same amount or slightly more secondary clauses in comparison to main clauses than men do. If we accept that many secondary clauses are an indication of a more varied language and of longer sentences, then women write these as much as men only when writing for women.

b) Word order: Word order in the Arabic of this material is of particular interest as the language of the majority population and the dominant language in Israel, Hebrew, is mostly an SVO language. ${ }^{31}$ Also, the colloquial Arabic is arguably of SVO order. ${ }^{32}$ Thus, under the possible influence of both Hebrew and colloquial Arabic, a preference for SVO order would be expected. However, other studies, like that of Parkinson, on Arabic in newspapers show that neither SVO order nor VSO order is clearly dominant in this kind (MSA of printed media) of Arabic. ${ }^{33}$

31 Albeit the order may be reversed frequently in the narrative and in secondary clauses.

32 This opinion is supported by among others Versteegh, while on the other hand disputed, at least when it comes to the narrative, by Dahlgren. S. O. Dahlgren, Word Order in Arabic (Gothenburg 1996); K. Versteegh, Pidginization and Creolization: The Case of Arabic (Amsterdam 1984), 21, 79.

33 D. Parkinson, 'VSO to SVO in Modern Standard Arabic: A Study in Diglossia Syntax', in Al-Arabiyya 14 (1981), pp. 24-37. 
In table 4, the preferred word order in main clauses is about the same for both alternatives when the expected reader is a woman, slightly higher (some 3 ) in favor of VS order when both genders are intended, and noticeably higher (21.75/29.65) for VS order when the articles are written for men. The opposite situation is, however, not found for secondary clauses. Here, SV or VS order is about equal for the groups with articles intended for men and women respectively. But in articles intended for both genders, three out of four secondary clauses have SV order.

Continuing with main clauses again, the following observations can be made from the results in table 5: While women as well as men write slightly more (2-3) VS order in articles intended for both genders, the preference for SV order in main clauses is clear only when women write for women. There the relation is 20.87 for SV to 6.3. Men writing articles intended for women, on the other hand, favor VS order more (more than double), and the same goes for articles by men writing for men $(7$ more). Women writing for men, on the contrary, have a tendency to use VS order instead. Continuing with the secondary clauses, both men and women prefer SV order in a relation of two out of three in articles written for both genders. Women writing for men also clearly favor SV order, while in articles for women both genders tend to write about half the secondary clauses in SV and half in VS order (more in favor of SV when men write and less, when women write).

Summary: Women prefer SV order in main clauses in articles for women, as well as in secondary clauses in articles written for men or for both genders. Women write VS order in the remaining groups both for main clauses and for secondary clauses only about 50 of the time, and with deviation from this rule of only a few percent. The exception is when the expected reader is a man. Then women use VS order in main clauses 7 more frequently. Thus, what is observable is that women prefer SV order or give both word orders equal frequency, except when the intended reader is a man. Men on the other hand seem to be in favor of a more traditional word order of MSA, that is VS order. This is clear in main clauses written for both women and men. In secondary clauses men prefer SV order clearly only when the article is for both genders. Otherwise SV order is slightly more 
frequent in articles for women and slightly less in articles for men. What is clear from the above is first, that women seem to favor SV order more than men, and, second, that the gender of the reader does make a difference, as women write more SV order both in main and secondary clauses when the reader is a man. Men, third, appear to prefer a more traditional VS order of MSA with the exception perhaps of secondary clauses.

c) Adjectives: Turning to adjectives, (table 4), the frequency of clauses where adjectives are found in articles intended for male readers is 15 higher than in articles intended for female readers, while articles for both genders render the average of the other two groups together (49.175 and 34.18), that is an average of 40.36. This is the opposite result of previous studies in other languages, where both genders used more adjectives when women were the intended readers. ${ }^{34}$

Women in all three groups (table 5) use fewer adjectives than men. ${ }^{35}$ In articles written for women and in those written for both genders, women writers use about half as many clauses with adjectives as do men (26.53 to 45.26 and 24.1 to 43.78 respectively), while women writing articles intended for men use fewer, yet when writing for women use the most clauses with adjectives, as do men (45.75 compared to 52.6).

Summary: Women use fewer clauses with adjectives than do men. However, when the intended reader of the articles is male, the frequency of clauses containing adjectives almost doubles. That means, clearly, that the gender of the reader influences the frequency of adjectives.

d) Adverbs: In the other registered word class (of table 4), adverbs, articles for men include, also, somewhat more clauses than is the case for the other groups (approximately 6.5). For the other two groups, the frequency is close to 11.5. In table 5 a comparison between the genders in the three groups shows that while the frequency in

34 Muchnik, 'Differences', Conclusion.

35 In this study all adverbs and adjectives are given the same value. 'Intensity' or other characteristics are not considered. 
women's use of adverbs is clearly higher in articles for men, even higher than when men write (19.5 to 14.25), and marginally higher than when men write for women (12.13 to 11.15$)$, women use only around half as many adverbs as men in articles for both genders (7.8 to 13.64$)$.

Summary: Adverbs are used in a higher percentage of clauses in articles for men than in articles for women. If we compare with previous research in other languages where women tend to use more intensive adverbs, ${ }^{36}$ we cannot be certain if this study is a replication or not. In articles for men, clauses with adverbs are certainly more frequent. However, 'intensity' is not considered here, as all adverbs are counted as equal. That makes it problematic to compare. Also, women writing articles for women show only a marginal difference.

e) Conjunction: As perhaps would be expected the conjunction $w a$ - is used considerably more often than its counterpart $f a$ - in all groups (table 4). Looking at table 5, in both genders and all groups the frequency of $w a$ - is also higher. Women writing for men and women writing for both genders use $f a$ - more frequently than do men in these groups (17.25 in comparison to as little as 3.9 and 17.87 to 10.38). Only in articles for women do men use relatively more $f a$ - than do women (8.2 to 15.7).

Summary: Women as well as men use clearly more $w a$ - than $f a$ - as conjunction. Women use $f a$ - in articles intended for men and for both genders with higher frequency. The only group where women use this conjunction with less frequency is in articles for women. There, on the other hand, men have a higher frequency of $f a$ - than in the other groups. The choice of this or the other conjunction is partly a question of style, at least when both are possible grammatically. The use of $f a$ with higher frequency could indicate an awareness of both grammar and style. If so, women writers write accordingly except for in articles intended for women, where men, on the contrary, have double as high a frequency.

36 M. L. Newman et al., 'Gender Differences in Language Use: an Analysis of 14.000 Text Samples’, in Discourse Processes 45 (2008), p. 230. 
f) Particle of negation: The choice for negating the past between the particles lam, which negates the imperfect in the jussive, or $m \bar{a}$, which negates the perfect, is a question of style. In all three groups, lam is the preferred particle of negation, from 75 of the findings in articles for women to 93.7 for both genders, and all the findings in articles for men. Women writing for women use $m \bar{a}$ as much as 33, but women choose only lam for the remaining groups. Men writing prefer $m \bar{a}$ in 10.5 of the cases only in articles intended for both genders, and in none of the other groups.

Summary: The particle lam is used in more than 65 of the findings irrespectively of the gender of the reader or the gender of the writer. Since these two particles are used exchangeably this choice is solely a matter of style. Varying one's choice of negation is varying in style. This kind of variation is the choice of women writers only when writing for women, and for men only when writing for both genders.

g) Ungrammaticalities: A brief look at the mistakes made in the three groups (table 4) does not present any major difference. The number of mistakes ranges between an average of 1 to 3.5 mistakes, and no obvious conclusion can be made in this regard concerning a preference for a certain grammatical or stylistic feature. Also, in table 5 , only a small increase is found in articles where either men or women write for both genders.

\section{Conclusion and Final Comments}

Women and men write different Arabic in the Israeli press. These differences are observable in the frequency of main and secondary clauses (i.e. in sentence length and in variation), in word order, in the frequency of clauses containing adjectives, as well as those containing adverbs. We see these differences in the frequency of verbs without any visible noun, as well as in the choice of conjunction and the choice of particle of negating the past. These variations in MSA are due to the gender of the reader, as is the case with adjectives, where women writers use markedly fewer adjectives than men do, except when writing for men. But the variation is otherwise dependent on the 
gender of the writer. This alternation is not between grammatical or ungrammatical Arabic. Indeed, both genders write correct Arabic. Instead it is (mostly) a question of choice, of style. We are perhaps not able to draw certain conclusions as to the reasons behind the differences. Assumptions as to why they exist are, however, possible to make. In the following, a few thought-provoking suggestions will be presented.

\section{Why are there differences in the use of Arabic?}

First hypothesis: Men writing in the Israeli press use Arabic more conservatively because of a stronger connection to the language of the Koran and classical literature. Their MSA is closer to the language of literature. Thus, they attempt to write a more archaic language. Indeed, several of the writers in the examined material are even, politically, Islamists, one or two are imams.

That men use a more traditional Arabic is observable in their preference for VSO word order. Even women, who otherwise prefer SVO word order, write VSO word order when writing for men. If men do have a more conservative view of Arabic, this would suggest that they are more resistant to influence both from the dominant surrounding language, Hebrew, and, from the spoken colloquial, both of which arguably have SVO word order. This goes for influence from other languages, such as English, as well.

However, a few writers are Islamists or imams. And even if the overwhelming majority of writers most likely are Muslims, this also includes almost all the women. Thus, a religious argument will not explain why Muslim men would write more conservatively than Muslim women.

Second hypothesis: A more reasonable suggestion is that women seem to be slightly more open to influence from either Hebrew or spoken colloquial Arabic (or English at the University), and would expect male readers to be less open to this kind of influence, which is why women writers tend to write more VSO order for male readers. The opposite also seems to apply. Men writing for women readers tend to use more SVO order. 
Men's preference for a more literary Arabic, would perhaps also be an argument when it comes to the higher frequency of adjectives and adverbs when men write, as well as when women write for men. A further point are the indications of more secondary clauses, in the language of men, i.e. longer and more complicated sentences when men write. Women, on the whole, use fewer sentences and a less complicated language. An oddity is that women use even fewer than their average when the readers are men.

Women are perhaps more open to external influence. This is reflected in a slightly less complicated language, with shorter sentences, as well as fewer adjectives and adverbs. Women writers seem to use a simpler language, that is concrete, with less ornament. Women also use more verbs in the first person when writing. This could be an indication of a stronger affiliation to themselves as individuals with personal preferences that might be seen as separate from mainstream or collective standings. If such a suggestion had credibility, it would possibly mean, for one thing, that the academic experience of Arab women, when experiencing the European or USlike secular university of Israel, is somewhat different from that of Arab men. Or, to put it in other words, perhaps it is a question of status identification, where women view themselves as having a slightly weaker standing in the traditional language and culture, than do men. The acceptance of more stylistic elements from other languages could be a manifestation of that.

The beauty of Arabic is arguably, among other features, found in its extensive usage of adjectives and adverbs, more so than is the case in, e.g. Hebrew. If male writers as well as male readers show a positive relation to more adjectives and adverbs in written Arabic, as well as a stronger preference for VSO word order, and, longer, more complex, sentences, this could be interpreted as a more conservative attitude towards Arabic among men. The most reasonable argument for a marginally different approach among women is that they are more open to external influence.

The above are but assumptions that would need further studies for verification. Whatever the underlying reasons, this study has established that there are indications for differences in written Arabic depending both on the gender of the writer and of the reader. 


\section{References}

Colley, A. et al. 'Style and Content in Emails and Letters to Male and Female Friends', in Journal of Language and Social Psychology, 23 (2004), pp. 369-378.

Dahlgren, S. O. Word Order in Arabic (Gothenburg 1996).

Fairclough, N. Language and Power (London 2001).

Fasold, R. W. Tense Marking in Black English: a Linguistic and Social Analysis (Arlington 1972).

Goddard, A. and L. M. Patterson. Language and Gender (London 2000).

Grootaers, W. 'Quelques remarques concernant le langage des femmes’, in Orbis 1 (1952), 82-85.

Haas, A. 'Male and Female Spoken Language Differences', in Psychological Bulletin 86 (1979), 616-626.

Haas, M. J. 'Men's and Women's Speech in Koasati', in D. Hymes (ed.), Language in Culture and Society (New York 1964).

Hellinger, M. 'Effecting Social Change through Group Action', in C. Kramarae, M. Schultz and W. O’Barr (eds.), Language and Power (Los Angeles 1984), pp. 136-153.

Inoue, M. 'Echoes of Modernity: Nationalism and the Enigma of "Women's Language" in Late Nineteenth Century Japan', in B. S. McElhinny, (ed.), Words, Worlds and Material Girls: Language, Gender, Globalization (New York 2007), 157-204.

Jespersen, O. Language, Its Nature, Development and Origin (London 1922).

Key, M. R. Male/Female Language (New York 1975).

Labov, W. Sociolinguistic Patterns (Philadelphia 1972). 
Lakoff, R. Language and Women's Place (New York 1975).

Lee, M. Y. 'The Married Women's Status and Role as Reflected in Japanese: an Exploratory Sociolinguistic Study', in Signs 1 (1976), 991-999.

Mehl, M. R. and J. W. Pennebaker, 'The Sounds of Social Life: a Psychometric Analysis of Students' Daily Social Environments and Natural Conversations', in Journal of Personality \& Social Psychology 84 (2003), pp. 857-870.

Miller, R. A. The Japanese Language (Chicago 1967).

Mills, S. Language and Sexism (New York 2008).

Moreau, N. B. 'Education, Ideology and Class/Sex Identity', in C. Kramarae, M. Schultz and W. O’Barr (eds.), Language and Power (Los Angeles 1984), 43-61.

Muchnik, M. 'Language Differences between Men and Women in Hebrew Journals’ (Ramat-Gan 1992).

Mulac, A. et al. 'Empirical Support for the Gender-as-Culture Hypothesis: an Intercultural Analysis of Male/Female Language Differences', in Human Communication Research (2001), pp. 121152.

Mulac, A. and T. L. Lundell, 'Effects of Gender-Linked Language Differences in Adults' Written Discourse: Multivariate Tests of Language Effects', in Language and Communication 14 (1994), pp. 299-309.

Newman, M. L. et al., 'Gender Differences in Language Use: an Analysis of 14,000 Text Samples', in Discourse Processes 45 (2008).

Parkinson, D. 'VSO to SVO in Modern Standard Arabic: A Study in Diglossia Syntax', in Al-Arabiyya 14 (1981), pp. 24-37. 
Saint-Jacques, B. 'Sex, Dependency and Language', I La Linguistique 9 (1973), pp. 89-96.

Sapir, E. Selected Writings in Language (Berkeley 1949).

Shibamoto, J. S. Japanese Women's Language (London 1985).

Silveira, J. ‘Generic Masculine Words and Thinking', in C. Kramarae, The Voices and Words of Women and Men (Oxford 1980), 165178.

Smith, P. M. 'Sex Markers in Speech', in I. K. Sherer and H. Giles, Social Markers in Speech (Cambridge 1979), 109-146.

Versteegh, K. Pidginization and Creolization: The Case of Arabic (Amsterdam 1984).

Weatherall, A. Gender, Language and Discourse (London 2002).

Weil, Sh. 'Women and Language in Israel', in International Journal of the Sociology of Language 41 (1983), 77-91. 